Article

\title{
Serving Local Fish in School Meals: The Nutritional Importance of Consuming Oily Fish
}

\author{
Sara Bonanomi ${ }^{1, *}$, Alessandro Colombelli ${ }^{1}\left(\mathbb{D}\right.$, Bruno Bucciarelli $^{2}$, Riccardo De Angelis ${ }^{2}$ and \\ Antonello Sala ${ }^{1,3}$ \\ 1 Italian National Research Council (CNR), Institute of Marine Biological Resources and \\ Biotechnologies (IRBIM), Largo Fiera della Pesca 1, 60125 Ancona, Italy \\ 2 Bucciarelli Laboratori Srl, Zona Industriale Basso Marino 112, 63100 Ascoli Piceno, Italy \\ 3 European Commission Joint Research Centre (JRC), Directorate of Sustainable Resources, Water and Marine \\ Resources Unit, 21027 Ispra (VA), Italy \\ * Correspondence: sara.bonanomi@cnr.it; Tel.: +39-071-207-8830; Fax: +39-071-55-313
}

Received: 5 June 2019; Accepted: 20 July 2019; Published: 23 July 2019

check for updates

\begin{abstract}
The European Food and Nutrition Action Plan 2015-2020 encourages Member States to promote local affordable and healthy dietary initiatives to support a sustainable food system, particularly in schools and public institutions where advertising on eating behaviour and food preferences is needed. In Italy, the promotion of healthy and sustainable diets, including the consumption of oily fish, is at an early stage. Based on the success of a unique Italian educational campaign in school lunch programmes, the aim of the present study was to compare the nutritional composition of locally caught anchovy and of imported frozen fillets of farmed Vietnamese pangasius, to observe the potential implications of this dietary substitution. Anchovy showed a significantly higher fatty acid and protein content than pangasius, and contained five times more lipids, mainly n-3 and n-6 polyunsaturated fatty acids. As previous studies confirmed, a diet providing large amounts of these fats is therefore recommended especially during childhood. The present findings highlight the high nutritional value and healthiness of serving locally caught fish in school meals, which plays a strong role in teaching good dietary habits for a lifetime. Further initiatives are needed to encourage responsible fish consumption during early life to promote a sustainable food system.
\end{abstract}

Keywords: school lunch programme; Italy; healthy nutrition; oily fish; sustainability

\section{Introduction}

Fish and seafood are major sources of important nutrients, such as essential fatty acids, proteins, vitamins, and micro-and macroelements [1]. In particular, they are high in polyunsaturated fatty acids (PUFA), mainly eicosapentaenoic acid (EPA), and docosahexaenoic acid (DHA), which provide documented health benefits, for instance by helping to reduce the risk of obesity, cardiovascular disease, age-related decline in multiple cognitive domains [2-4] and to enhance fetal development $[5,6]$. Oily fish, such as anchovy, sardine, mackerel and tuna-like have been linked to many of these health benefits $[7,8]$. Scientists together with global health advisory organisations recommend to the general adult population the consumption of at least one portion of oil-rich fish per week [9]. However, while the supply of fish is increasing in most countries, Europeans apparently only consume half of the recommended amount [10]. According to the European Food and Nutrition Action Plan 2015-2020 [11], Member States should promote local affordable and healthy dietary initiatives to support a sustainable food system, particularly in those settings such as schools and public institutions where advertising on eating behaviour and food preferences is needed $[12,13]$. Teaching good dietary habits early in life would help healthy ageing and maximize smart food choices for a lifetime. Furthermore, eating 
locally, especially in school meal programmes would encourage fish consumption during childhood and would strengthen local communities and economies.

Although the promotion of sustainable fish diets in schools across Europe exists, it is still limited to a few countries (e.g., UK and Portugal [14]; France [15]). In Italy, this is a recent development [16]. For instance, since 2013, Pappa Fish: Eat Well, Grow Healthy! a preliminary food educational campaign mainly financed by the European Maritime and Fisheries Fund (EMFF) and partly financed by local municipalities in the Marche region located in the central-east part of Italy, on the Adriatic coast, has been launched with the aim to introduce local oily fish and seafood into regional school canteens [16,17]. This was a unique initiative in Italy that connected a large number of stakeholders (i.e., public schools across local governments, administrators, school cafeteria workers, nutrition technologists, parents, teacher committees, school directors and the whole fishing industry) to educate new generations to a sustainable consumption of fish with high nutritional value. Between 2015 and 2017, the initiative involved 282 schools (approximately 30,000 children) based in 42 municipalities of the Marche region and a total of 90 tons of local seafood products used to prepare about 49,500 daily meals [16,17]. Meals were prepared by chefs and canteen committees with local fresh oily fish and seafood from the Adriatic Sea and were seasonally included in primary and secondary school canteen menus in Marche region. As part of the educational campaign, children were involved in over 800 practical workshops divided into more than 200 activities. Children were also trained and guided with storytelling and creative games to get to know the benefits and the high nutritional value of local fish and sea products coming from the Adriatic Sea. In this contest, it is important to understand clearly the nutritional implications of replacing imported frozen fish with local and seasonal fish. The replacement of low-cost imported fish products with locally caught species will certainly benefit local economies, promoting and supporting an affordable and sustainable food system, but whether this economic advantage would also translate into an improvement in the nutritional profile of the product supplied remains uncertain. From a nutritional quality perspective, does the consumption of local fish products constitute a dietary improvement?

The purpose of this study is to compare the nutritional composition of two representatives of both local and imported products present on the Italian market, in this case: local anchovy and imported frozen fillets of farmed Vietnamese pangasius. These two species are normally found in the meals served in school canteens $[17,18]$. Among the 15 local marine species considered in the Pappa Fish educational campaign see [16,17], the European anchovy (Engraulis encrasicolus) was chosen for chemical analysis as it is the major oily fish and one of the most important target species in the Italian commercial fisheries $[19,20]$. The Vietnamese pangasius (Pangasius hypophthalmus), instead, was considered as one of the most popular imported fish consumed in the European Union (EU), competing on the market with other white fish species like tilapia, hake, cod, haddock, Nile perch and Alaska pollock [21]. The European Union (EU) represents the largest pangasius importer, accounting for about the $22 \%$ of exported Vietnamese frozen pangasius fillets [22]. In this contest, we also discuss the importance of eating local healthy sustainable diets during childhood.

\section{Materials and Methods}

Fatty acid and protein content, ammonia concentration, and $\mathrm{pH}$ value were determined in three groups of fish samples:

- 24 fresh European anchovies (E. encrasicolus) caught by and obtained from professional fishermen in the Adriatic Sea (FHA);

- 24 frozen European anchovies (E. encrasicolus) caught by and obtained from professional fishermen in the Adriatic Sea (FRA);

- 8 frozen fillets of farmed Vietnamese pangasius purchased from a supermarket (FRP). 
FHA and FRA (the latter thawed at room temperature, $25^{\circ} \mathrm{C}$ ) were gutted, headed, filleted and homogenised separately in a blender for about $60 \mathrm{~s}$ at $13,000 \mathrm{rpm}$ and used to prepare 8 samples of muscle tissue, each weighing about $30 \mathrm{~g}$ (corresponding to 3 specimens). In the case of FRP fillets, the glaze liquid released by thawing was accurately removed and the drained fillets were homogenised in a blender for about $60 \mathrm{~s}$ at 13,000 rpm. Eight samples of muscle tissue, each weighing about $100 \mathrm{~g}$ (corresponding to one FRP fillet) were prepared for the analyses. A total number of 24 samples (8 per group) were analysed.

The fat content was determined according to the Soxhlet extraction method [23,24] and the ISTISAN Report 1996/34 [25,26]. Samples were weighed and placed into a cellulose extraction cartridge; the Soxhlet apparatus, containing the cartridge, was introduced into a distillation flask containing $150 \mathrm{~mL}$ of $\mathrm{n}$-hexane and a few anti-bumping granules. Samples were extracted for $220 \mathrm{~min}$ (30-40 cycles/h), then the solvent was removed using a vacuum rotary evaporator. Overall, the extraction procedure took approximately $4 \mathrm{~h}$. Fatty acids were then separated by gas chromatography according to ECC Regulations [27] using an Agilent/HP 6890 GC gas chromatograph according to ECC Regulations (Reg. ECC 2568/1991 11/07/1991 GU ECC L248; Reg. ECC 1429/1992 GU ECC L150). Proteins were determined using the copper catalyst Kjeldahl method [27] and the ISTISAN Report 1996/34 [25,26]. The procedure involves sample digestion with concentrated sulphuric acid using copper (II) sulphate as a catalyst, to convert organic nitrogen to ammonia, alkalisation, distillation of the liberated ammonia into an excess of boric acid solution, and titration with hydrochloric acid to determine the ammonia bound by the boric acid. The nitrogen content of the sample is calculated based on the amount of ammonia produced. Ammonia was determined by [24] $\mathrm{pH}$ was measured in samples homogenised with one part of deionised water according to $[28,29]$. All analyses were performed at the laboratory of Gruppo Bucciarelli srl (Ascoli Piceno, Italy). R software was used for the statistical analyses. Saturated Fatty Acids (SFA), Monounsaturated Fatty Acids (MUFA), PUFA, and ammonia concentrations, protein content, and $\mathrm{pH}$ values were visualised in a heat map using hierarchical clustering analysis and subjected to the Kruskal-Wallis test. The level of significance was set at $p<0.05$. If significance was met, a post hoc Nemenyi test adjusted to $\chi^{2}$ statistics was performed for pairwise multiple comparisons of mean rank sums.

\section{Results}

The results of the chemical analyses of FHA, FRA and FRP are reported as mean \pm the standard

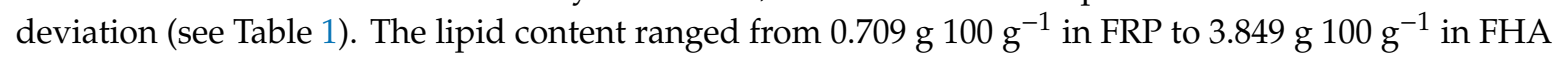
and was highest in FHA and FRA; the difference was significant $(p<0.05)$. The protein values were significantly higher $(p<0.05)$ in FHA and FRA compared with FRP. The ammonia concentration was highest in FHA (194.6 $\left.\mathrm{mg} \mathrm{kg}^{-1} ; p<005\right)$ and lowest in FRP $\left(42.00 \mathrm{mg} \mathrm{kg}^{-1} ; p<0.05\right)$. The $\mathrm{pH}$ value ranged from 6.4 to 8.0 (Table 1) and was highest in FRP (up to 8.008).

Table 1. Proximate composition of fresh E. encrasicolus (FHA), frozen E. encrasicolus thawed at room temperature, $25^{\circ} \mathrm{C}$ (FRA) and frozen farmed Vietnamese pangasius (FRP) fillets. Values are reported as mean \pm standard deviation.

\begin{tabular}{cccc}
\hline & FRP & FRA & FHA \\
\hline Lipids * $^{*}$ & $0.709 \pm 0.022$ & $3.783 \pm 0.133$ & $3.849 \pm 0.117$ \\
Protein $^{* *}$ & $15.18 \pm 0.725$ & $19.56 \pm 0.675$ & $19.72 \pm 0.675$ \\
Ammonia $^{* *}$ & $42.00 \pm 4.140$ & $194.6 \pm 7.089$ & $163.3 \pm 10.44$ \\
\hline pH & $8.008 \pm 0.043$ & $6.516 \pm 0.013$ & $6.483 \pm 0.019$ \\
\cline { 2 - 3 } Lipid and protein values are expressed as g $100 \mathrm{~g} \mathrm{~g}^{-1} ;{ }^{* *}$ Ammonia values are expressed as $\mathrm{m} \mathrm{kg}^{-1}$.
\end{tabular}


The fatty acids composition of the three sample groups is reported in Figure 1 and Table 2. Their total SFA, MUFA, and PUFA content varied significantly $(p<0.05$; Table 3$)$. Although similar fatty acids patterns (PUFA $>$ SFA $>$ MUFA) were found in all three sample groups, values in FRP fillets were 10 times lower $(p<0.05)$. Palmitic acid (C16:0) was the most abundant SFA in anchovy samples, accounting for more than 50\% of total SFA, whereas stearic acid (C18:0) was the predominant SFA in FRP fillets; the concentrations of pentadecylic (C15:0), arachidic (C20:0), and heneicosylic (C21:0)

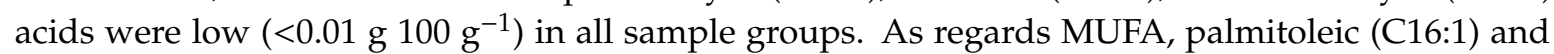
oleic (C18:1n9c) acids were the most abundant in all fillet groups, whereas gadoleic (C20:1) and erucic (C22:1n9t) acids showed the lowest concentrations. With regard to PUFA, n-3 FA accounted for more than $90 \%$ of the total PUFA content in all three groups. DHA (C22:6n3) and EPA (C20:5n3) were the predominant fatty acids in all groups, DHA accounting for more than $50 \%$ and more than $31 \%$ of total PUFA, respectively. $n-6$ fatty acids accounted for more than $50 \%$ of PUFA in FHA and FRA fillets and for less than $10 \%$ in FRP samples.

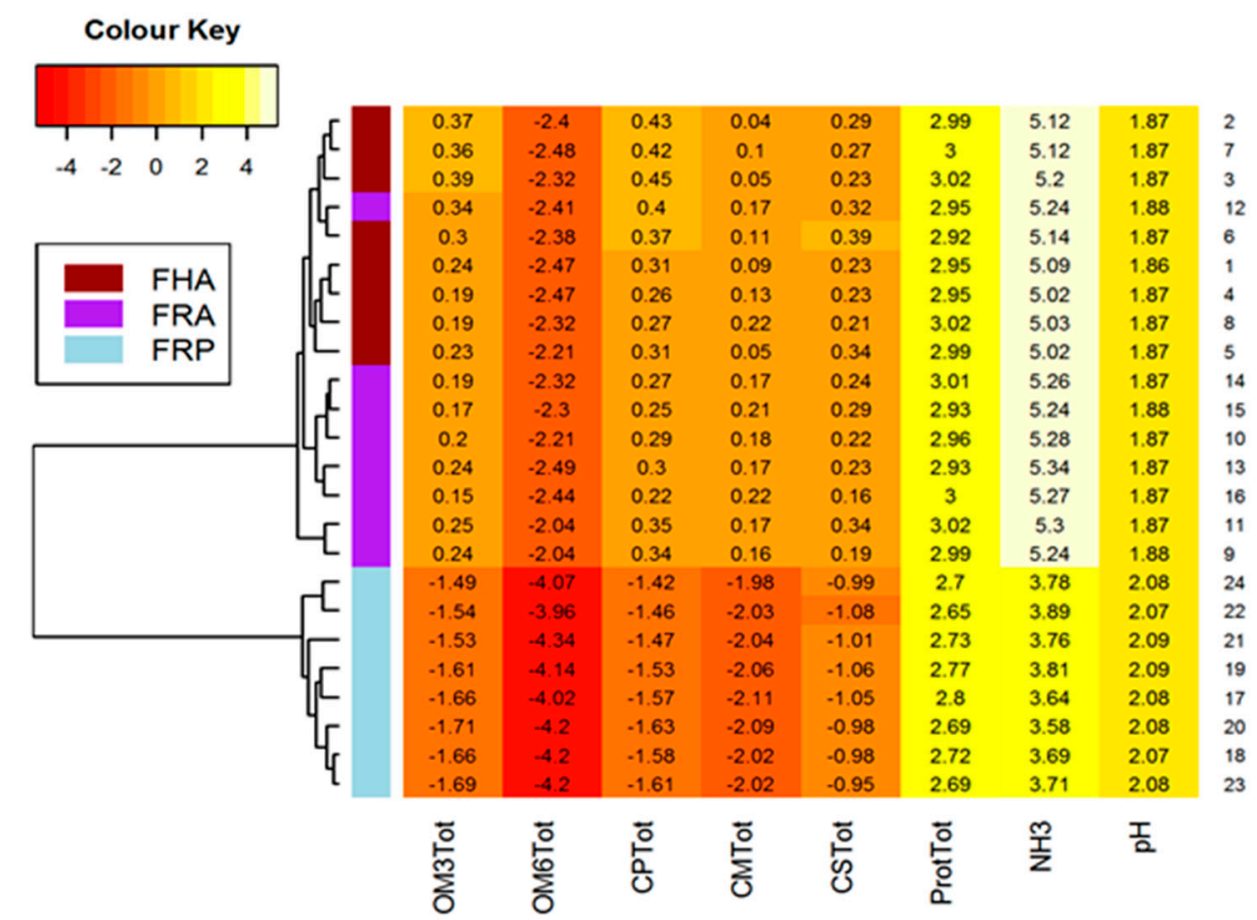

Figure 1. Heat map showing the differences in polyunsaturated fatty acids (PUFA), Monounsaturated Fatty Acids (MUFA), Saturated Fatty Acids (SFA) and protein content, ammonia concentrations and $\mathrm{pH}$ values among E. encrasicolus (FHA), E. encrasicolus thawed at room temperature, $25^{\circ} \mathrm{C}$ (FRA), and farmed Vietnamese pangasius (FRP) fillets. Values are expressed in logarithmic scale. The colour gradient, from white to red, reflects increasing nutrient concentrations.OM3Tot $=\mathrm{n}-3$ fatty acids content; OM6Tot = n- 6 fatty acids content; CPTot $=$ Total PUFA content CMTot =Total MUFA content; CSTot $=$ Total SFA content; ProtTot $=$ Total protein content; NH3 = Ammonia concentration; $\mathrm{pH}=\mathrm{pH}$ values. 
Table 2. Fatty acid profile ( $100 \mathrm{~g}^{-1}$ ) of FHA, FRA and FRP fillets. Values are reported as mean \pm standard deviation. C 12:0 = Lauric acid; C 14:0 = Myristic acid; C 15:0 = Pentadecylic acid; C 16:0 $=$ Palmitic acid; $C$ 18:0 = Stearic acid; C 20:0 = Arachidic acid; C 21:0 = Heneicosylic acid; C 16:1 = Palmitoleic acid; C 18:1n9c = Oleic acid; C 20:1 = Gadoleic acid; C 22:1n9t = Erucic acid; C 18:2n6c $=$ Linoleic acid; C 18:2n6t $=$ Linolelaidic acid; C 18:3n3 $=\alpha$-Linolenic acid; C 18:3n6 $=\gamma$-Linolenic acid; C 20:2 = Eicosadienoic acid; C 20:3n3 = Eicosatrienoic acid; C 20:3n6 = Homo- $\gamma$-Linolenic acid; C 20:5n3 = Dpan3 acid; C 22:2 = Docosadienoic acid; C 22:6n3 = Docosahexaenoic acid; Total n-6 = Total omega- 6 fatty acids; Total n-3 = Total omega- 3 fatty acids; $n-3 / n-6=$ Ratio of omega- 6 to omega-3 fatty acids.

\begin{tabular}{|c|c|c|c|}
\hline Fatty Acids & FRP & FRA & FHA \\
\hline \multicolumn{4}{|l|}{ Saturated, SFA } \\
\hline C 12:0 & $0.0225 \pm 0.00338$ & $0.0157 \pm 0.00341$ & $0.01512 \pm 0.00331$ \\
\hline C 14:0 & $0.0668 \pm 0.00356$ & $0.2900 \pm 0.03591$ & $0.2975 \pm 0.03732$ \\
\hline C $15: 0$ & $<0.01$ & $<0.01$ & $<0.01$ \\
\hline C 16:0 & $0.0742 \pm 0.00471$ & $0.7437 \pm 0.04533$ & $0.7525 \pm 0.03955$ \\
\hline C 18:0 & $0.2000 \pm 0.01851$ & $0.2350 \pm 0.02927$ & $0.2543 \pm 0.03852$ \\
\hline C 20:0 & $<0.01$ & $<0.01$ & $<0.01$ \\
\hline C 21:0 & $<0.01$ & $<0.01$ & $<0.01$ \\
\hline Total SFA & $0.3636 \pm 0.01631$ & $1.2845 \pm 0.08412$ & $1.3188 \pm 0.08598$ \\
\hline \multicolumn{4}{|c|}{$\begin{array}{c}\text { Monounsaturated, } \\
\text { MUFA }\end{array}$} \\
\hline C $16: 1$ & $0.0427 \pm 0.00500$ & $0.4250 \pm 0.02563$ & $0.3375 \pm 0.04773$ \\
\hline C $18: 1 n 9 c$ & $0.0476 \pm 0.00366$ & $0.6637 \pm 0.03814$ & $0.6587 \pm 0.03136$ \\
\hline C 20:1 & $0.0196 \pm 0.00226$ & N.R. $<0.1$ & N.R. $<0.1$ \\
\hline C $22: 1 n 9 t$ & $0.0195 \pm 0.00325$ & $0.1087 \pm 0.01959$ & $0.1087 \pm 0.01807$ \\
\hline Total MUFA & $0.1295 \pm 0.00537$ & $1.1975 \pm 0.02492$ & $1.1050 \pm 0.06866$ \\
\hline \multicolumn{4}{|c|}{ Polyunsaturated, PUFA } \\
\hline C $18: 2 \mathrm{n} 6 \mathrm{c}$ & $0.0160 \pm 0.00192$ & $0.1035 \pm 0.01837$ & $0.0930 \pm 0.00888$ \\
\hline C $18: 2 \mathrm{n} 6 \mathrm{t}$ & N.R. $<0.1$ & N.R. $<0.1$ & N.R. $<0.1$ \\
\hline C $18: 3 n 3$ & $0.0175 \pm 0.00218$ & $0.0137 \pm 0.00168$ & $0.0122 \pm 0.00225$ \\
\hline C $18: 3 n 6$ & N.R. $<0.1$ & N.R. $<0.1$ & N.R. $<0.1$ \\
\hline C 20:2 & N.R. $<0.1$ & N.R. $<0.1$ & N.R. $<0.1$ \\
\hline C $20: 3 n 3$ & N.R. $<0.1$ & N.R. $<0.1$ & N.R. $<0.1$ \\
\hline C 20:3n6 & N.R. $<0.1$ & N.R. $<0.1$ & N.R. $<0.1$ \\
\hline C $20: 5 n 3$ & $0.0672 \pm 0.00523$ & $0.4387 \pm 0.03090$ & $0.4512 \pm 0.03870$ \\
\hline C 22:2 & N.R. $<0.1$ & N.R. $<0.1$ & N.R. $<0.1$ \\
\hline C 22:6n3 & $0.1212 \pm 0.01642$ & $0.8012 \pm 0.07754$ & $0.8687 \pm 0.08007$ \\
\hline Total n-6 & $0.0160 \pm 0.00192$ & $0.1035 \pm 0.01837$ & $0.0930 \pm 0.00888$ \\
\hline Total n-3 & $0.2002 \pm 0.01622$ & $1.2513 \pm 0.07581$ & $1.3322 \pm 0.10863$ \\
\hline Total PUFA & $0.2162 \pm 0.01673$ & $1.3548 \pm 0.07986$ & $1.4252 \pm 0.10777$ \\
\hline$n-3 / n-61$ & $12.661 \pm 1.79714$ & $12.402 \pm 2.20971$ & $14.444 \pm 1.82757$ \\
\hline
\end{tabular}


Table 3. $\mathrm{P}$ value of each pairwise comparisons of the mean concentrations of Monounsaturated Fatty Acids (MUFA), polyunsaturated fatty acids (PUFA), Total n-6, Total n-3, SFA, $\mathrm{NH}_{3}, \mathrm{pH}$ and protein among the three samples groups (FHA, FRA and FRP). The colour gradient, from red to white, corresponds to increasing $p$ values.

\begin{tabular}{|c|c|c|}
\hline MUFA & & \\
\hline & FHA & FRA \\
\hline FRA & 0.23648 & - \\
\hline FRP & 0.039 & 0.00012 \\
\hline \multicolumn{3}{|l|}{ PUFA } \\
\hline FRA & 0.63393 & - \\
\hline FRP & 0.00055 & 0.01418 \\
\hline \multicolumn{3}{|c|}{ Total n-6 } \\
\hline FRA & 0.75809 & - \\
\hline FRP & 0.01014 & 0.00081 \\
\hline \multicolumn{3}{|c|}{ Total n-3 } \\
\hline FRA & 0.67652 & - \\
\hline FRP & 0.00064 & 0.01278 \\
\hline \multicolumn{3}{|l|}{ SFA } \\
\hline FRA & 0.8521 & - \\
\hline FRP & 0.0012 & 0.0079 \\
\hline \multicolumn{3}{|l|}{ NH3 } \\
\hline FRA & 0.077 & - \\
\hline FRP & 0.077 & 0.000035 \\
\hline \multicolumn{3}{|l|}{$\mathrm{pH}$} \\
\hline FRA & 0.16 & - \\
\hline FRP & 0.000072 & 0.05 \\
\hline \multicolumn{3}{|l|}{ Protein } \\
\hline FRA & 0.9393 & - \\
\hline FRP & 0.0017 & 0.0056 \\
\hline
\end{tabular}

\section{Discussion}

School lunch programmes are important for children's health, for their education and for their future wellbeing. By introducing culinary traditions in schools and school canteens, children should set the pattern for healthy habits in adult life. According to previous investigations, the traditional low consumption at early age of saturated fatty acids and the higher intake of complex carbohydrates (e.g., legumes and cereals) decreased in the Southern European countries including Italy [30]. Mediterranean countries are passing through a 'nutritional transition' in which problems of undernutrition coexist with overweight, obesity and diet-related chronic diseases [31]. The erosion of the Mediterranean diet heritage, by the loss of its adherence among Mediterranean populations, is alarming, as it has undesirable impacts not only on health but also on social, cultural, economic and environmental trends in the Mediterranean region [30]. In this contest, initiatives like Pappa Fish can contribute to increase the effectiveness of Mediterranean diet in Italy, promoting it as an educational model for nutrition and health promotion in public schools.

In the present study, local caught anchovy and frozen fillets of farmed Vietnamese pangasius were subjected to proximal composition analysis. The results demonstrated that anchovy fillets are characterised by higher nutrient concentrations than Vietnamese pangasius; in particular, their lipid content is five times higher than that of pangasius fillets. According to science-based nutrition standards, the anchovy lipid content is equivalent to that of low-fat meat $(2-4 \%)$, whereas the content determined in pangasius fillets is similar to that found in lean meat $(<2 \%)$ [32]. Total SFA, MUFA, and PUFA concentrations varied significantly between the two species. Similar FA profiles have been described in sardine, salmon, and herring [33,34]. Moreover, data analysis showed that the total n-3 and n-6 PUFA were 6-10 times higher in fresh and frozen anchovy, making them a valuable nutritional resource. Notably, fish and seafood are the only major dietary source of n-3 PUFA [1], which help 
prevent cardiovascular disease, age-related decline in multiple cognitive domains [2-4] and enhance fetal development $[5,6]$.

Anchovy also had a higher protein content, as reported in an earlier study [33]. The lower protein content determined in Vietnamese pangasius has previously been described in fillets sold on different European markets (e.g., Italy [34]; Poland [35]; Germany [36]). According to [37] and similar studies [32,34-36], fish with high amounts of protein must contain greater than $15 \%$. Furthermore, processing often involves the addition of large amounts of polyphosphates, which may increase water-binding capacity, thus reducing protein content [32,36].

The $\mathrm{pH}$ value - together with the concentration of ammonia and other substances-is a reliable indicator of freshness/spoilage [32,38]. The almost neutral $\mathrm{pH}$ found in anchovy fillets indicated that they have a good nutritional value. In contrast, the $\mathrm{pH}$ measured in the pangasius fillets, combined with their lower protein content, and reflected loss of freshness. These data agree with studies documenting that $\mathrm{pH}$ gradually increases during enzymatic protein degradation [36]. The ammonia concentration, which reflects the degradation of nitrogenous compounds, was higher in anchovy indicating that fresh fish should be consumed within 2-3 days.

The analyses performed in this study documented that locally caught anchovy had a higher nutritional value. PUFA accounted for a large proportion of total lipids. $n-3$ and n-6 PUFA, which help prevent several diseases, especially cardiovascular conditions [2,3,39], accounted for $35-40 \%$ of total lipids. As previous studies confirmed [7-9], a diet providing large amounts of these fats is therefore recommended especially during childhood $[12,13]$. Even though pangasius showed a good n-3/n-6 ratio, it has a considerably lower content in healthy fats [40].

The present study focused on the nutritional importance of a single local and important commercial species-the European anchovy—introduced in the Italian school lunch programme Pappa Fish. Further analysis, including more oily fish species, can be conducted to enhance the relevance of consuming local fish products. Eating small schooling species like anchovies can also reduce the carbon footprint because their fishing does not require farming or care of livestock like pangasius demands. To date, there is no study establishing the typical carbon footprint $(\mathrm{CF})$ of frozen pangasius fillets imported to Europe. However, in [41] the assessment of carbon footprints of seafood consumed in Australia revealed that Vietnamese pangasius had the highest $\mathrm{CF}$ compared to other imported fish species at $9 \mathrm{~kg} \mathrm{CO}_{2} \mathrm{e} \mathrm{kg}^{-1}$, a higher footprint than hake $\left(5.3 \mathrm{~kg} \mathrm{CO}_{2} \mathrm{e} \mathrm{kg}{ }^{-1}\right)$, and frozen salmon and flathead (both around $3 \mathrm{~kg} \mathrm{CO}_{2} \mathrm{e} \mathrm{kg}^{-1}$ ). The $98 \%$ of its $\mathrm{CF}$ was linked to the production process, with only $2 \%$ attributable to the transport phase. The farm stage in Vietnam was identified as the major source of carbon emissions for imported frozen seafood. Farmed fish in fact require the availability of feed, of variable nature and origin, that take energy to grow or catch, and then more energy in the processing stages. It is also suggested in [41] that in some cases, imported products can have lower $\mathrm{CF}$ than domestic products, but that production and transportation mode are important since they often generate more impact than distance travelled. On the other hand, wild caught seafood has often a lower CF than other animal proteins, but the generated impact varies greatly with the fishery involved. The most efficient fisheries are those targeting small schooling pelagic species like anchovies (Engraulidae), mackerel (Scombridae) and sardines (Cupleidae), while crustaceans' fisheries resulted among the least efficient form of animal protein production [42]. Unfortunately, small pelagic fisheries are often overlooked as a food option and instead used as an intermediate product in aquaculture and livestock production [42]. A comprehensive ecological footprint assessment of seafood consumed in Europe is clearly needed. Thus, the replacement of imported Vietnamese pangasius with local caught anchovy can be consider a step forward towards the enhance of a sustainable food system.

This study offers relevant information in view of the introduction of healthy and local fish and seafood in school meals in Italy. Consuming fish with high n-3 and n-6 polyunsaturated fatty acids content is crucial, since these fats can only come from the diet and oily fish, such anchovies, are one of the best sources. Anchovies caught in the Adriatic Sea are a traditional dietary staple of coastal communities [43] and they are perceived as highly healthy local products with a good nutritional 
profile, but difficult to cook [44]. As a result, many consumers prefer to buy less expensive products that are also easier to prepare (e.g., farmed fish fillets [45]). Awareness campaigns aimed at regular and occasional Italian consumers have recently been organized to promote the knowledge and image of local fishery products, highlighting underutilized local species as potential drivers of regional and national economic development $[16,17,46,47]$. However, none have explicitly recommended increasing their consumption for the health benefits they confer, underlining expressly their nutritional properties. Therefore, more information on the intrinsic quality attributes of local fish products and on their economic importance in EU is required.

\section{Conclusions}

The present study highlights the nutritional implications of replacing low-cost imported fish products with locally caught species. The results of the chemical analyses documented the high nutritional value of local anchovy fillets in terms of PUFA content and protein profile. Serving local fish products in school meals, which have excellent nutritional properties, play a strong role in in teaching good dietary habits for a lifetime. Further initiatives should be enhanced to encourage responsible fish consumption during early life and to support a sustainable food system.

Author Contributions: A.S. and S.B. conceived the project; B.B. and R.D.A. conducted the chemical analyses; S.B. performed the statistical analyses; A.C. drew the heat map; A.C. critically commented on the manuscript at all stages; S.B. wrote the paper with input from the other authors.

Funding: This research was funded by the European project "BENTHIS: Benthic ecosystem fisheries impact study" (KBBE 2012.1.2-09, Grant Agreement No. 312088), financed by the EC Commission through the Seventh Framework Programme.

Acknowledgments: We are grateful to Marche Region for providing the information related to the educational campaign Pappa Fish. We are grateful to the anonymous referees for their useful comments.

Conflicts of Interest: The authors declare no conflict of interest.

\section{References and Notes}

1. Taşbozan, O.; Gökçe, M.A. Fatty Acids in Fish. In Fatty Acids; Angel, C., Ed.; In Tech: London, UK, 2017; pp. 143-159.

2. Albracht-Schulte, K.; Kalupahana, N.S.; Ramalingam, L.; Wang, S.; Rahman, S.M.; Robert-McComb, J.; Moustaid-Moussa, N. Omega-3 fatty acids in obesity and metabolic syndrome: A mechanistic update. J. Nutr. Biochem. 2018, 58, 1-16. [CrossRef] [PubMed]

3. Siscovick, D.S.; Barringer, T.A.; Fretts, A.M.; Wu, J.H.; Lichtenstein, A.H.; Costello, R.B.; Kris-Etherton, P.M.; Jacobson, T.A.; Engler, M.B.; Alger, H.M.; et al. Omega-3 Polyunsaturated Fatty Acid (Fish Oil) Supplementation and the Prevention of Clinical Cardiovascular Disease: A Science Advisory from the American Heart Association. Circulation 2017, 13, e867-e884. [CrossRef] [PubMed]

4. Rest, O.; Wang, Y.; Barnes, L.L.; Tangney, C.; Bennett, D.A.; Morris, M.C. APOE $\varepsilon 4$ and the associations of seafood and long-chain omega-3 fatty acids with cognitive decline. Neurology 2016, 86, 2063-2070. [CrossRef] [PubMed]

5. Bloomingdale, A.; Guthrie, L.B.; Price, S.; Wright, R.O.; Platek, D.; Haines, J.; Oken, E. A qualitative study of fish consumption during pregnancy. Am. J. Clin. Nutr. 2010, 92, 1234-1240. [CrossRef] [PubMed]

6. Coletta, J.M.; Bell, S.J.; Roman, A.S. Omega-3 Fatty Acids and Pregnancy. Rev. Obstet. Gynecol. 2010, 3, 163-171. [PubMed]

7. Lane, K.E.; Derbyshire, E.J. Omega-3 fatty acids-A review of existing and innovative delivery methods. Crit. Rev. Food Sci. Nutr. 2018, 58, 62-69. [CrossRef]

8. Sprague, M.; Dick, J.R.; Tocher, D.R. Impact of sustainable feeds on omega-3 long-chain fatty acid levels in farmed Atlantic salmon, 2006-2015. Sci. Rep. 2016, 6, 21892. [CrossRef] [PubMed]

9. Raatz, S.; Silverstein, J.; Jahns, L.; Picklo, M. Issues of fish consumption for cardiovascular disease risk reduction. Nutrients 2013, 5, 1081-1097. [CrossRef] 
10. Westhoek, H.; Lesschen, J.P.; Rood, T.; Wagner, S.; De Marco, A.; Murphy-Bokern, D.; Leip, A.; Grinsven, H.; Sutton, M.A.; Oenema, O. Food choices, health and environment: Effects of cutting Europe's meat and dairy intake. Glob. Environ. Chang. 2014, 26, 196-205. [CrossRef]

11. World Health Organization (WHO). European Food and Nutrition Action Plan 2015-2020 (Internet). 2014. [cited 2015 May 15]. Available online: http://www.euro.who.int/en/about-us/governance/regionalcommittee-for-europe/64th-session/documentation/working-documents/eurrc6414-european-food-andnutrition-action-plan-2015-2020 (accessed on 30 May 2019).

12. Cauwenberghe, E.; Maes, L.; Spittaels, H.; Lenthe, F.J.; Brug, J.; Oppert, J.M.; Bourdeaudhuij, I. Effectiveness of school-based interventions in Europe to promote healthy nutrition in children and adolescents: Systematic review of published and 'grey' literature. Br. J. Nutr. 2010, 103, 781-797. [CrossRef]

13. Birt, C.; Buzeti, T.; Grosso, G.; Justesen, L.; Lachat, C.; Lafranconi, A.; Mertanen, E.; Rangelov, N.; Sarlio-Lähteenkorva, S. Healthy and Sustainable Diets for European Countries; EUPHA: Utrecht, The Netherlands, 2017.

14. Weichselbaum, E.; Gibson-Moore, H.; Ballam, R.; Buttriss, J.L. Nutrition in Schools across Europe: A Summary Report of a Meeting of European Nutrition Foundations. Nutr. Bull. 2010, 36, 124-141. [CrossRef]

15. Vieux, F.; Dubois, C.; Duchêne, C.; Darmon, N. Nutritional Quality of School Meals in France: Impact of Guidelines and the Role of Protein Dishes. Nutrients 2018, 10, 205. [CrossRef] [PubMed]

16. EUMOFA. EU Consumer Habits Regarding Fishery and Aquaculture Products; Final Report; EUMOFA: Brussels, Belgium, 2017.

17. Pappa Fish Video Report. Available online: youtube.com/watch?v=V5thXoMfpys (accessed on 30 May 2019).

18. EUMOFA. The EU Fish Market; Directorate-General for Maritime Affairs and Fisheries of the European Commission: Brussels, Belgium, 2015; p. 66.

19. FAO. The State of Mediterranean and Black Sea Fisheries; General Fisheries Commission for the Mediterranean: Rome, Italy, 2018; p. 172.

20. Prato, E.; Biandolino, F. Total lipid content and fatty acid composition of commercially important fish species from the Mediterranean, Mar Grande Sea. Food Chem. 2012, 131, 1233-1239. [CrossRef]

21. EUMOFA. European Market Observatory for Fisheries and Aquaculture Products Monthly Highlights; EUMOFA: Brussels, Belgium, 2018.

22. EUMOFA. Pangasius Imported in the EU. Monthly Highlights No. 4/2014, European Market Observatory for Fisheries and Aquaculture Products; EUMOFA: Brussels, Belgium, 2014.

23. AOAC Official Method 920.39. Fat (Crude) or Ether Extract in Animal Feed, 18th ed.; AOAC International: Gaithersburg, MD, USA, 2005.

24. AOAC Official Method 999.01. Volatile bases in fish, ammonia ion selective electrode method. In $A O A C$ Official Methods of Analysis; AOAC: Gaithersburg, MD, USA, 2002; Volume II, Chapter 35; pp. 34-35.

25. Baldini, M.; Fabietti, F.; Giammarioli, S.; Onori, R.; Orefice, L.; Lipidi, S.A. Metodi di Analisi Utilizzati Per il Controllo Chimico Degli Alimenti; Rapporti ISTISAN 96/34; International Committee of Medical Journal Editors, pp. 39-40.

26. Baldini, M.; Fabietti, F.; Giammarioli, S.; Onori, R.; Orefice, L.; Stacchini, A. Ceneri Metodi di Analisi Utilizzati Per il Controllo Chimico Degli Alimenti; Rapporti ISTISAN 96/34; International Committee of Medical Journal Editors, pp. 78-79.

27. EEC 2568/91. Characteristics of olive and olive pomance oils and their analytical methods. Off. J. Eur. Communities 1991, L248, 1-82.

28. AOAC Official Method 950.46. Moisture in Meat. In Official Methods of Analysis, 15th ed.; AOAC International: Arlington, VA, USA, 1990.

29. AOAC Official Method 981.12. pH of Acidified Foods; AOAC: Gaithersburg, MD, USA, 1982.

30. International Centre for Advanced Mediterranean Agronomic Studies/Food and Agriculture Organization of the United Nations. Mediterranean Food Consumption Patterns: Diet, Environment, Society, Economy and Health; A White Paper Priority 5 of the Expo Milan 2015 Feeding Knowledge Programme; FAO: Rome, Italy, 2015.

31. Belahsen, R. Cultural diversity of sustainable diets. Nutrition transition and food sustainability. Proc. Nutr. Soci. 2014, 73, 385-388. [CrossRef] [PubMed]

32. Guimarães, C.F.M.; Mársico, E.T.; Monteiro, M.L.G.; Lemos, M.; Mano, S.B.; Conte-Junior, C.A. The chemical quality of frozen Vietnamese Pangasius hypophthalmus fillets. Food Sci. Nutr. 2016, 4, 398-408. [CrossRef] [PubMed] 
33. Kaya, Y.; Turan, H. Comparison of protein, lipid and fatty acids composition of anchovy (Engraulis encrasicolus L. 1758) during the commercial catching season. J. Muscle Foods 2010, 21, 474-483. [CrossRef]

34. Orban, E.; Nevigato, T.; Lena, G.; Masci, M.; Casini, I.; Gambelli, L.; Caproni, R. New trends in the seafood market. Sutchi catfish (Pangasius hypophthalmus) fillets from Vietnam: Nutritional quality and safety aspects. Food Chem. 2008, 110, 383-389. [CrossRef]

35. Usydus, Z.; Szlinder-Richert, J.; Adamczyk, M.; Szatkowska, U. Marine and farmed fish in the Polish market: Comparison of the nutritional value. Food Chem. 2011, 126, 78-84. [CrossRef]

36. Karl, H.; Lehmann, I.; Rehbein, H.; Schubring, R. Composition and quality attributes of conventionally and organically farmed Pangasius fillets (Pangasius hypophthalmus) on the German market. Int. J. Food Sci. Technol. 2010, 45, 56-66. [CrossRef]

37. Stansby, M.E. Chemical characteristics of fish caught in the northeast Pacific Ocean. Mar. Fish. Rev. 1976, 38, 1-11.

38. Islami, S.N.; Faisal, M.; Akter, M.; Reza, M.S.; Kamal, M. Comparative shelf life study of whole fish and fillets of cultured striped catfish (Pangasianodon hypophthalmus) during ice storage condition. Res. Agric. Livest. Fish. 2015, 2, 177-183. [CrossRef]

39. Lai, H.T.; Oliveira, M.C.; Lemaitre, R.N.; McKnight, B.; Song, X.; King, I.B.; Chaves, P.H.; Odden, M.C.; Newman, A.B.; Siscovick, D.S.; et al. Serial circulating omega 3 polyunsaturated fatty acids and healthy ageing among older adults in the Cardiovascular Health Study: Prospective cohort study. BMJ 2018, 363, k4067. [CrossRef] [PubMed]

40. Strobel, C.; Jahreis, G.; Kuhnt, K. Survey of n-3 and n-6 polyunsaturated fatty acids in fish and fish products. Lipids Health Dis. 2012, 11, 144. [CrossRef] [PubMed]

41. Farmery, A.K.; Gardner, C.; Green, B.S.; Jennings, S.; Watson, R.A. Domestic or imported? An assessment of carbon footprints and sustainability of seafood consumed in Australia. Environ. Sci. Policy 2015, 54, 35-43. [CrossRef]

42. Parker, R.W.; Tyedmers, P.H. Fuel consumption of global fishing fleets: Current understanding and knowledge gaps. Fish Fish. 2015, 16, 684-696. [CrossRef]

43. Lucchetti, A.; Piccinetti, C.; Meconi, U.; Frittelloni, C.; Marchesan, M.; Palladino, S.; Virgili, M. Transferable Fishing Concessions (TFC): A pilot study on the applicability in the Mediterranean Sea. Mar. Policy 2012, 44, 438-447. [CrossRef]

44. Dernini, S.; Berry, E.M.; Serra-Majem, L.; La Vecchia, C.; Capone, R.; Medina, F.X.; Aranceta-Bartrina, J.; Belahsen, R.; Burlingame, B.; Calabrese, G.; et al. Med Diet 4.0: The Mediterranean diet with four sustainable benefits. Public Health Nutr. 2017, 20, 1322-1330. [CrossRef]

45. Cosmina, M.; Demartini, E.; Gaviglio, A.; Mauracher, C.; Prestamburgo, S.; Trevisan, G. Italian consumers' attitudes towards small pelagic fish. New Medit 2012, 11, 52-57.

46. Bonanomi, S.; Colombelli, A.; Malvarosa, L.; Cozzolino, M.; Sala, A. Towards the Introduction of Sustainable Fishery Products: The Bid of a Major Italian Retailer. Sustainability 2017, 9, 438. [CrossRef]

47. EUMOFA; The EU Fish Market. European Market Observatory for Fisheries and Aquaculture Products, 2016th ed.; European Commission: Brussel, Belgium, 2016.

(C) 2019 by the authors. Licensee MDPI, Basel, Switzerland. This article is an open access article distributed under the terms and conditions of the Creative Commons Attribution (CC BY) license (http://creativecommons.org/licenses/by/4.0/). 